\title{
Sexual types of flowers morphology in Heracleum sibiricum (Apiaceae)
}

\author{
Vladimir Godin ${ }^{1 *}$, and Zanetta Ialamova ${ }^{1}$ \\ ${ }^{1}$ Moscow Pedagogical State University, 129164, Moscow, Kibalchicha str., 6, bldg. 3, Russia
}

\begin{abstract}
According to the structural features of Hecaleum sibiricum flowers, three sexual types of flowers are distinguished, bisexual, pistillate, and staminate. In pistillate flowers a reduction of androecium and its parts is observed, and a reduction of gynoecium, with the exception of stylopodium there is in staminate flowers. The three sexual types of flowers in a umbellet are significantly distinguished by their size that is decreased in the following row: bisexual - pistillate - staminate. The reasons of such changes are discussed.
\end{abstract}

\section{Introduction}

Most apioids are characterized by a self-compatibility system [1]. Therefore, many species of the family have an original set of adaptations that promote and favour xenogamy and outbreeding such as the presence of strictly expressed dichogamy (a protandry, most often, or a protogyny, very seldom), the formation of pseudanthia, different types of sexual systems, as well as the specific sequence of flowering in umbellets and in umbels as parts of a synflorescence [2-5]. Andromonoecy is the most frequent sexual system in Apiaceae $[4,6,7]$. Although other sexual systems are pretty rare in the family and are recorded in a few genera. On the other side, there are at least eighteen genera that include gynodioecious species: Azorella Lam., Bolax Comm. ex Juss., Gingidia J.W. Dawson, Heracleum L., Peucedanum L., Seseli L. and others [8, 9].

The genus Heracleum includes 120-130 species, wide spread in Europe, Asia, North America, and Africa [9]. The study of sexual systems in species of the genus has a pretty long history. P. Knuth [10] reported that different species of hogweeds produced perfect and staminate flowers. J. Hegi [11] mentioned about unisexual and perfect flowers in Heracleum. Perfect, staminate, and pistillate flowers were observed in the various species of Heracleum: H. antasiaticum Manden., H. asperum (Hoffm.) M. Bieb., H. carpaticum Porc., H. dissectum Ledeb., H. ponticum (Lipsky) Schischk. ex Grossh. and others [12]. According to the data of G. E. Grosset [13], H. sibiricum is a gynodioecious plant when perfect flowers produce on some individuals, and pistillate flowers on others. This author showed that there are few $(3.3 \%)$ portion of female in the populations of $H$. sibiricum.

\footnotetext{
* corresponding author: vn.godin@mpgu.su
} 
Thus, H. sibiricum is sexually polymorphic species that produce at least two or three types of flowers. Our aim is to identify sexual dimorphism in $H$. sibiricum in the Moscow region.

\section{Materials and methods}

Heracleum sibiricum L. is a biennial or perennial semi-rosette herbaceous plant with a tap root system, mono- or polycarpic. H. sibiricum has a Eurasian area. Observations were made in natural populations in the Moscow region. The species was monitored between 2015 and 2019 throughout the flowering period. Developmental stages were recorded at least three times a week. The flowers were collected in terminal, secondary, tertiary and quaternary umbels. The perfect and unisexual flowers in $H$. sibiricum can be clearly distinguished during flowering by their stylopodium and ovary size and their stamens position. The perfect, bisexual or hermaphrodite flowers, have both functional stamens and pistils, that set well developed fruits. Pistillate, male sterile flowers, have functional pistils, produce sterile pollen-sacs and are thus functionally female. Staminate flowers produce only rudimentary styles and are thus male. A total of 100 perfect, 100 pistillate, and 100 staminate flowers of $H$. sibiricum were analysed. The morphology of the flowers is described according to R. C. McLean, W. R. Ivimey-Cook [14]. The size of the flower parts was measured by means of a Biomed MS-1 stereoscopic microscope. The obtained data were processed using methods of variation statistics [15]. For each character, the limits of its variation (min-max), mean value $(\mathrm{M})$ and its error $(\mathrm{m})$ were determined. Comparison of arithmetic means was performed with Student's t-test. The calculation results are presented in table 1 .

\section{Results}

According to our data, three sexual types of flowers, perfect, pistillate and staminate, are produced by $H$. sibiricum in the Moscow region. H. sibiricum generate compound umbels which are termed umbels with umbellets. Umbels and umbellets are indeterminate (without terminal flowers).

\subsection{Perfect flowers.}

Perfect flowers are perigynous, four-circle, heteromeric: pentameric in the perianth and androecium and dimeric in the gynoecium. According to several authors [9, 12], $H$. sibiricum flowers are classified as actinomorphic or almost actinomorphic, however, as we will show below, they are actinomorphic only in the corolla.

Table 1. Morphological characters of perfect, pistillate, and staminate flowers in Heracleum sibiricum

\begin{tabular}{|c|c|c|c|c|c|}
\hline Characters & Flower & $\begin{array}{c}\text { Terminal } \\
\text { umbel }\end{array}$ & $\begin{array}{c}\text { Secondary } \\
\text { umbel }\end{array}$ & $\begin{array}{c}\text { Tertiary } \\
\text { umbel }\end{array}$ & $\begin{array}{c}\text { Quaternary } \\
\text { umbel }\end{array}$ \\
\hline \multirow{3}{*}{ Corolla diameter, mm } & $\mathrm{b}$ & $5.32 \pm 0.09$ & $5.02 \pm 0.06$ & $4.74 \pm 0.14$ & $4.46 \pm 0.11$ \\
\cline { 2 - 6 } & $\mathrm{p}$ & $5.02 \pm 0.08$ & $4.71 \pm 0.05$ & $-^{*}$ & - \\
\cline { 2 - 6 } & $\mathrm{s}$ & $4.55 \pm 0.03$ & $4.01 \pm 0.04$ & $2.86 \pm 0.04$ & $2.29 \pm 0.03$ \\
\hline \multirow{3}{*}{ Petal length, mm } & $\mathrm{b}$ & $1.91 \pm 0.07$ & $1.78 \pm 0.03$ & $1.73 \pm 0.04$ & $1.63 \pm 0.05$ \\
\cline { 2 - 6 } & $\mathrm{p}$ & $1.77 \pm 0.06$ & $1.65 \pm 0.02$ & - & - \\
\cline { 2 - 6 } & $\mathrm{s}$ & $1.76 \pm 0.04$ & $1.64 \pm 0.04$ & $1.35 \pm 0.09$ & $1.22 \pm 0.06$ \\
\hline \multirow{2}{*}{ Petal width, mm } & $\mathrm{b}$ & $1.52 \pm 0.07$ & $1.49 \pm 0.05$ & $1.33 \pm 0.05$ & $1.12 \pm 0.06$ \\
\cline { 2 - 6 } & $\mathrm{p}$ & $1.38 \pm 0.06$ & $1.31 \pm 0.06$ & - & - \\
\hline
\end{tabular}




\begin{tabular}{|c|c|c|c|c|c|}
\hline & $\mathrm{s}$ & $1.34 \pm 0.02$ & $1.26 \pm 0.02$ & $0.84 \pm 0.02$ & $0.59 \pm 0.03$ \\
\hline \multirow{3}{*}{ Stamens length, mm } & $\mathrm{b}$ & $2.37 \pm 0.02$ & $2.23 \pm 0.10$ & $2.24 \pm 0.03$ & $2.12 \pm 0.03$ \\
\hline & $\mathrm{p}$ & $1.73 \pm 0.02$ & $1.67 \pm 0.08$ & - & - \\
\hline & $\mathrm{s}$ & $2.16 \pm 0.05$ & $2.12 \pm 0.08$ & $1.50 \pm 0.08$ & $1.48 \pm 0.05$ \\
\hline \multirow{3}{*}{ Anthers length, mm } & $\mathrm{b}$ & $0.94 \pm 0.02$ & $0.91 \pm 0.04$ & $0.84 \pm 0.02$ & $0.81 \pm 0.02$ \\
\hline & $\mathrm{p}$ & $0.59 \pm 0.02$ & $0.58 \pm 0.01$ & - & - \\
\hline & $\mathrm{s}$ & $0.89 \pm 0.04$ & $0.76 \pm 0.01$ & $0.71 \pm 0.03$ & $0.69 \pm 0.02$ \\
\hline \multirow{3}{*}{ Anther width, mm } & $\mathrm{b}$ & $0.74 \pm 0.02$ & $0.75 \pm 0.05$ & $0.72 \pm 0.01$ & $0.72 \pm 0.02$ \\
\hline & $\mathrm{p}$ & $0.50 \pm 0.01$ & $0.49 \pm 0.01$ & - & - \\
\hline & $\mathrm{s}$ & $0.75 \pm 0.01$ & $0.68 \pm 0.01$ & $0.57 \pm 0.02$ & $0.56 \pm 0.02$ \\
\hline \multirow{2}{*}{$\begin{array}{l}\text { Length of the polar axis of } \\
\text { pollen grains, } \mu \mathrm{m}\end{array}$} & $\mathrm{b}$ & $36.1 \pm 0.6$ & $34.5 \pm 0.5$ & $33.1 \pm 0.7$ & $32.2 \pm 0.6$ \\
\hline & $\mathrm{S}$ & $36.8 \pm 0.4$ & $36.0 \pm 0.7$ & $36.6 \pm 0.3$ & $35.3 \pm 0.3$ \\
\hline \multirow{2}{*}{$\begin{array}{l}\text { Equatorial diameter of pollen } \\
\text { grains, } \mu \mathrm{m}\end{array}$} & $\mathrm{b}$ & $23.1 \pm 0.6$ & $21.1 \pm 0.5$ & $19.5 \pm 0.3$ & $19.2 \pm 0.2$ \\
\hline & $\mathrm{s}$ & $20.8 \pm 0.4$ & $20.6 \pm 0.5$ & $21.0 \pm 0.3$ & $20.2 \pm 0.2$ \\
\hline \multirow{2}{*}{ Pollen fertility, \% } & $\mathrm{b}$ & $95.2 \pm 3.2$ & $93.7 \pm 3.8$ & $92.3 \pm 3.1$ & $93.1 \pm 3.3$ \\
\hline & $\mathrm{S}$ & $96.3 \pm 3.1$ & $95.2 \pm 3.6$ & $94.4 \pm 3.4$ & $92.3 \pm 3.8$ \\
\hline \multirow{3}{*}{$\begin{array}{l}\text { Abaxial stytopodium length, } \\
\mathrm{mm}\end{array}$} & $\mathrm{b}$ & $1.19 \pm 0.05$ & $1.09 \pm 0.02$ & $0.87 \pm 0.02$ & $0.70 \pm 0.03$ \\
\hline & $\mathrm{p}$ & $1.18 \pm 0.04$ & $1.07 \pm 0.03$ & - & - \\
\hline & $\mathrm{s}$ & $0.83 \pm 0.04$ & $0.83 \pm 0.01$ & $0.82 \pm 0.01$ & $0.69 \pm 0.02$ \\
\hline \multirow{3}{*}{$\begin{array}{l}\text { Abaxial stylopodium height, } \\
\mathrm{mm}\end{array}$} & $\mathrm{b}$ & $1.96 \pm 0.04$ & $1.84 \pm 0.03$ & $1.50 \pm 0.05$ & $1.28 \pm 0.04$ \\
\hline & $\mathrm{p}$ & $1.93 \pm 0.03$ & $1.83 \pm 0.02$ & - & - \\
\hline & $\mathrm{s}$ & $1.45 \pm 0.02$ & $1.36 \pm 0.04$ & $1.20 \pm 0.02$ & $0.96 \pm 0.02$ \\
\hline \multirow{2}{*}{ Ovary length, mm } & $\mathrm{b}$ & $1.84 \pm 0.05$ & $1.48 \pm 0.06$ & $1.12 \pm 0.05$ & $0.90 \pm 0.02$ \\
\hline & $\mathrm{p}$ & $1.83 \pm 0.05$ & $1.47 \pm 0.05$ & - & - \\
\hline \multirow{2}{*}{ Style length, mm } & $\mathrm{b}$ & $0.95 \pm 0.02$ & $0.85 \pm 0.03$ & $0.35 \pm 0.02$ & $0.32 \pm 0.02$ \\
\hline & $\mathrm{p}$ & $0.94 \pm 0.02$ & $0.83 \pm 0.02$ & - & - \\
\hline \multirow{2}{*}{ Stigma diameter, $\mathrm{mm}$} & $\mathrm{b}$ & $0.41 \pm 0.02$ & $0.34 \pm 0.02$ & $0.17 \pm 0.01$ & $0.15 \pm 0.01$ \\
\hline & $\mathrm{p}$ & $0.40 \pm 0.02$ & $0.32 \pm 0.03$ & - & - \\
\hline
\end{tabular}

Note. ${ }^{*}$ - pistillate flowers are absent in tertiary and quaternary umbels. $\mathrm{b}$ - bisexual flowers, $\mathrm{p}-$ pistillate flowers, $\mathrm{s}-$ staminate flowers.

Pedicels range from very long (in the marginal flowers of a umbellet) to long (in the middle and inner flowers of a umbellet). The rays of a umbellet (pedicels) are unequal: they are the longest in the marginal flowers, toward the centre of a umbellet they are reduced. Pedicels are thin (less than the diameter of the ovary), pubescent, ribbed. The pedicels can be deviated (for the most flowers in umbellets) or horizontal (for some marginal flowers of umbellets). The pedicels are curved: they deviate from their vertical axis at an acute angle upwards (especially in marginal flowers of umbellets).

Perianth is divided into a calyx and a corolla. The calyx of $H$. sibiricum is absent. The corolla is separate, pentameric. The aestivation of the flower is valvate (the sides of next petals are adjacent or sometimes touch). Petals are monochromatic, yellow-green, obovate, not deeply retracted at the apex, almost horizontal, with the apex bent inward (with respect to the vertical axis of the flower), falling off (after flowering of the flower).

Androecium is free, pentameric, haplostemenous (stamens are located in one circle). The stamens are attached by the lower end of the stamen filament to the receptacle, attached between the petals and alternate with them, bent inward in their apex, equal, longer than the corolla. Filaments are curved at the apex, slightly awl-shaped (gradually thinning towards the apex), thin (much smaller than the diameter of the anthers), smooth. Anthers are tetrasporangiate, pollen sacs are paired in pairs in two thecae. The pollen sacs in the thecae before opening the anthers merge because of the destruction of the partitions between them, as a result of the anthers become bisporangiate. Anthers are attached to the stamen filaments with the dorsal side in the middle, close together (the thecae are separated by a very narrow connective), apical, equal to all the stamens of the flower, uniform, 
elliptical, free, open intrinsically longitudinally by cracks. After emptying, anthers dry and fall.

The pollen grains are 3-celled, tricolporate, triangular in polar view, and elongated in equatorial view.

Gynoecium is bicarpellate, syncarpous. Ovary is half-lower, oblong, ribbed, bilocular, with one developed ovule in each loculus. The styles are lateral (coming out from the side of the ovary), straight, short (shorter than the ovary), thin, loose (not fused with each other), bare, remaining in the ovary and retaining their shape after the flower wilting. During their growth, styles change their position to the axis of the flower: at the beginning, they are upright (located vertically to the axis of the flower), when they mature and after flowering, they become deflected towards the stylopodia, the lower expanded parts of the styles at the point of their attachment to ovaries. The stigma is apical, small (looks small compared to the size of the style and ovary), simple (not divided into parts), capitate, matte until ripe and shiny when ripe, covered with papillae, slightly bent (slightly deviated from the vertical axis of the style). Abaxial and adaxial stylopodium differ in size, 1.19 and $1.08 \mathrm{~mm}$ (respectively). Such difference is one of the reasons why $H$. sibiricum flowers is zygomorphic. Another reason is the relative position of two carpels and five stamens in the flowers through which it is impossible to draw more than one plane of symmetry.

The nectaries are intrafloral, confined to the ovary and located above it, they are the under-pillars (stylopodium, nectariferous discs) of a conical shape, wavy along the edge.

Perfect flowers in $H$. sibiricum are located in terminal, secondary, tertiary, and quaternary umbels. A comparison of the perfect flowers size and their parts from different parts of synflorescence showed the following (Table 1). In general, the parameters of perfect flowers and their structural elements sequentially decrease in a row from terminal to quaternary umbels. This is especially noticeable by such characters as the diameter of the corolla, the size of the stylopodium, ovaries, styles and stigmas, when there are significant differences between the flowers on the same branch order. On the contrary, characters such as the size of the petals and the parameters of the androecium, depend on the position of the flower in the structure of synflorescence to a lesser extent. Nevertheless, these structural elements also noticeably decrease in flowers on quaternary umbels. However, the size of pollen grains does not depend on the flower position in terminal, secondary, tertiary, or quaternary umbels.

\subsection{Pistillate flowers}

Structural differences between perfect and pistillate flowers in $H$. sibiricum by features of the perianth and its parts, gynoecium and its parts are not observed. However, the reduction of androecium and its parts is noted in pistillate flowers. In pistillate flowers, the stamens are underdeveloped, $70-80 \%$ less than the size of the stamens in perfect flowers. Stamens in pistillate flowers have pale yellow anthers and always remained in a bent position despite opening the corolla. After blooming the pistillate flowers, their stamens twisted, dried out and fell off along with the petals. Straightening or opening of anthers did not occur. Some pistillate flowers produce completely sterile pollen, pollen grains were much smaller than in perfect flowers.

Pistillate flowers were found only in terminal and secondary umbels. In general (Table 1), the sizes of pistillate flowers and their parts decrease in a row terminal - secondary umbels, however, these differences are not always significant. Thus, the pistillate flowers in the terminal umbel are bigger than the ones of the secondary umbels in the diameter of the corolla, the length and width of the abaxial stylopodia, the length of the ovary and the diameter of the stigmas. 


\subsection{Staminate flowers}

Differences between staminate and perfect flowers in the structure of the perianth and its parts, as well as androecium and its elements were not detected. In staminate flowers, a reduction of many elements of gynoecium and its components is observed. Two types of staminate flowers can be distinguished according to the structural features of the reduced gynoecium. Many staminate flowers don't produce styles completely while stylopodia that play the role of nectaries are preserved. Such structurally staminate flowers occupy the most central position in umbellets. In a few staminate flowers, very short styles are observed, but their stigmas never ripen for pollen. In the ovary of such flowers, as well as in the ovary of perfect flowers, four ovules are distinguishable, moreover, all of them are totally sterile. After the flowering of such staminate flowers, their ovaries growth slightly and sometimes pericarp formation occurs, but no seeds are formed.

Staminate flowers can be found in compound umbels from terminal to quaternary (Table 1). In general, miniaturization of the staminate flowers and their parts is observed in a row terminal - quaternary umbels. A very noticeable change in the size of staminate flowers is observed when comparing secondary and tertiary umbels, for example, the diameter of the corolla decreases by almost $70 \%$.

Thus, the size of perfect, pistillate, and staminate flowers decrease with an increasing of branching order. Many authors showed such regularity in the different apioids $[1,2,5]$. According to many surveys $[1,2,4]$, a decrease the flowers size is connected to unequal conditions for the growth and development of flowers in umbels of different branch order. There is the different degree of accessibility of nutrients that influence on size differences between flowers located in terminal, secondary, tertiary, and quaternary umbels.

\subsection{Comparison of the sizes of different types of flowers}

An analysis of the size of bisexual, pistillate, and staminate flowers in H. sibiricum which are located in umbels of the same branch order, showed the following (Table 1). In a number of morphological characters, bisexual flowers and their structural elements are larger than similar parts of pistillate flowers. Such characters include the characters of the corolla and its parts, and the androecium and its elements. The sizes of female organs do not reliably differ between bisexual and pistillate flowers. Similar patterns are manifested in compound terminal and secondary umbels. Staminate flowers are always smaller than pistillate flowers (Table 1). Bisexual flowers and their structural elements are always larger than the same parts of staminate flowers. On the other hand, there is no difference between the size of the androecium of the two types flowers in terminal and secondary umbels. The size of different parts of androecium in the staminate flowers are significantly smaller than in bisexual flowers in tertiary and quaternary umbels.

Therefore, in H. sibiricum, there is a dimensional differentiation of bisexual, pistillate, and staminate flowers, which is associated with a number of factors. The smaller overall sizes of staminate flowers compared to bisexual and pistillate are due to their different spatial arrangement in umbellets. Staminate flowers in $H$. sibiricum are always located in the centre of umbellets. According to many surveys [1, 2, 5, 16], a decrease of the size of flowers and their parts is noted toward the centre of umbellets. Such regularity is characterized by both for one sexual type of flower within a umbellet, and for different sexual types of flowers with different positions in the umbel $[2,5]$. The differences between bisexual and pistillate flowers are not due to their different arrangement in umbellets. Both types of flowers have marginal location in umbellets. Grosset [13] showed and our studies are confirmed that $H$. sibiricum belongs to gynodioecious species. Many authors showed that there are significant size differences between bisexual and pistillate flowers in 
gynodioecious species $[8,17,18]$. To explain such differences in gynodioecious species, there is a hypothesis of "developmental-correlation", which assumes that between petals and stamens exist a consistent growth and / or genetic correlation $[8,18,19]$. A number of authors [19] showed that hormones secreted by the stamens influence the growth of the corolla. Numerous next studies $[17,18]$ found that the reduction of anthers and pollen at an early stage of flower development is more detrimental to the size of the corolla of pistillate flowers in gynodioecious species compare with their degeneration at later stages. Additional confirmation of the mutual influence of the forming petals and stamens in the flower was convincingly demonstrated by $\mathrm{ABC}$, and later by $\mathrm{ABCDE}$, a molecular biological model of flower development [20]. According to the ABCDE model, the development of the calyx, corolla, androecium and gynoecium in the flowers is determined by genes belonging to the five classes (A, B, C, D, and E). At the same time, it has been shown that the products of the $\mathrm{A}+\mathrm{B}+\mathrm{E}$ genes are necessary for the formation of petals, and $\mathrm{B}+\mathrm{C}+\mathrm{E}$ for stamens [20]. Thus, there are at least two groups of genes (B and $\mathrm{E})$ that determine the development of petals and stamens.

\section{References}

1. C.R. Bell, Breeding systems and floral biology of the Umbelliferae or evidence for specialization in unspecialized flowers, in The Biology and Chemistry of the Umbelliferae, (London, 1971)

2. K. Reuther, R. Claßen-Bockhoff, Plant Div. Evol. 128, 181 (2010)

3. V.N. Godin, Russ. J. Ecol. 48, 433 (2017)

4. V.N. Godin, T.V. Perkova, Botanicheskii Zhurnal 102, 35 (2017)

5. V.N. Godin, S.V. Dozorova, T.V. Arkhipova, Vestnik Tomskogo Gosudarstvennogo Universiteta. Biol 45, 47 (2019)

6. M.A. Schlessmann, Plant Div. Evol. 128, 233 (2010)

7. V.N. Godin, Contemp. Probl. Ecol. 5, 337 (2012)

8. V.N. Godin, E.I. Demyanova, Botanicheskii Zhurnal 98, 1465 (2013)

9. G.M. Plunkett, M.G. Pimenov, J.P. Reduron, E.V. Kljukov, B.E. van Wyk, T.A. Ostroumova, M.J. Henwood, P.M. Tilney, K. Spalik, M.F. Watson, B.Y. Lee, F.D. Pu, C.J. Webb, J.M. Hart, A.D. Mitchell, B. Muckensturm, Springer 15, 9 (2018)

10. P. Knuth, Handbuch der Blütenbiologie, Leipzig 2 (1898)

11. J. Hegi Illustrierte Flora von Mittel-Europa, Munchen 5 (1926)

12. K.G. Tkachenko, Rastitelnye resursy 25, 52 (1989)

13. G. Je. Grosset, Bulleten MOIP. Otd. Biol 79, 57 (1974)

14. R.C. McLean, W.R. Ivimey-Cook, Textbook of theoretical botany, (London 1956)

15. R.R. Sokal, F.J. Rohlf, Biometry: the principles and practice of statistics in biological research (New-York, 2012)

16. C.J. Webb, New Zealand J. Bot. 19, 335 (1981)

17. L.F. Delph, L.F. Galloway, M.L. Stanton, Amer. Natur. 148, 299 (1996)

18. V.N. Godin, Botanicheskii Zhurnal 105, 236 (2020)

19. A. Plack, Nature 180, 1218 (1957)

20. J. Liu, C.-Q. Li, Y. Dong, X. Yang, Y.-Z. Wang, BMC Plant Biol. 18, 341 (2018) 